\title{
Önértékelő kérdőív fejlesztése a kollaboratív problémamegoldó képességet leíró modellek egyikének validálására: a kollaboratív komponens vizsgálata
}

\author{
Pásztor-Kovács Anita, ${ }^{*}$ Pásztor Attila** és Molnár Gyöngyvér***
}

Jelen tanulmány a csoportban történő problémamegoldó képesség kollaborativ komponensét vizsgáló önértékelő kérdőív kialakitásának folyamatát, továbbá kipróbálásának eredményeit mutatja be. A kérdöív fejlesztése kettős célt szolgált. Egyrészt egy olyan, a kollaborativ problémamegoldó képességet leiró elméleti modellek egyikére épülő mérőeszközt kívántunk kialakitani, amely egyén szintjén nyújt átfogó (és nem egyetlen esetre reflektáló) visszacsatolást a tanulók kollaborativ képességeiröl, másrészt célunk volt a kollaborativ problémamegoldó képesség struktúrájának mélyebb megismerése, az elméleti modellek egyikének empirikus tesztelése, validálása. A kérdöívet az Assessment \& Teaching of 21st Century Skills projekt elméleti modelljének kollaboratív komponensére építettük. Összesen 36 tételt fejlesztettünk a három fö képesség, ezen belül a kilenc részképesség vizsgálatára. A tanulók ötfokú skála segítségével értékelték, hogy mennyire jellemző rájuk egy adott állitás. A kérdőiv működését online nagymintás adatfelvétel keretein belül teszteltük nyolcadik évfolyamos tanulók körében $(N=871)$ az eDia rendszeren keresztül. Megerösítő faktoranalizist alkalmazva elemeztük, hogy kimutatható-e az elméleti modell változókészletünk mögött. Az alacsony faktorsúlyú tételek szelektálása után az új, 17 tételes redukált skála megfelelő illeszkedést mutatott a háromdimenziós modellel ( $\chi 2=386,06 d f=116 ; p<0,01 ; C F I=0,918 ; T L I=0,904 ; R M S E A=0,052)$, azaz a három fö képességet (részvétel, nézöpontátvétel, szociális szabályozás) egyértelmúen kimutattuk a kollaborativ komponens mögött. A 17 tételes röviditett skála (Cronbach- $\alpha=0,91)$ és annak három alskálája (Cronbach- $\alpha=0,70-0,85)$ megfeleló szintű reliabilitás mutatóval rendelkezett, a kérdőiv tehát kellő megbizhatósággal ad becslést a diákok kollaborativ képességeinek fejlettségi szintjérôl.

Kulcsszavak: kollaboratív képességek, kollaboratív problémamegoldás, együttmúködés, kollaboráció, kollaboratív képességek kérdőív

\section{Bevezetés}

A kollaboratív, azaz csoportban történő problémamegoldás képessége egyre fontosabb értéket képvisel a 21. században [Binkley et al., 2012; National Research Council, 2011; a képességet collaborative problem solving skills, illetve collaborative problem solving competence néven illeti elsősorban a szakirodalom, a fogalom magyar nyelvű bevezetésekor Nagy József (2003) képességfogalmát vettük alapul (a fordítással kapcsolatos megfontolásainkat részletesen Isd. Pásztor-Kovács, 2015)]. A problémamegoldást igénylő munkák nagy részét ma már csoportok végzik, emellett a hagyományosabb gyártómunkák, kézzel végzett tevékenységek is ritkán képzelhetőek el anélkül, hogy ne legyen szükséges a másokkal történő együttmúködés (Kanter, 1994; Salas, Cooke \& Rosen, 2008). A csoportos problémamegoldás igénye a munka világának minden színterén megjelenik, és amennyiben a csoport tagjai kompetensek, növeli is a munkahely produktivitását, legyen szó vállalati vagy közszféráról, egészségügyi, katonai vagy tudományos szféráról (Brannick, Prince, Prince \& Salas, 1995; Cannon-

\footnotetext{
Szegedi Tudományegyetem, Neveléstudományi Intézet, pasztor-kovacs@edpsy.u-szeged.hu

** MTA-SZTE Képességfejlődés Kutatócsoport, attila.pasztor@edu.u-szeged.hu

*** Szegedi Tudományegyetem, Neveléstudományi Intézet, Oktatáselméleti Kutatócsoport, gymolnar@edpsy.u-szeged.hu
} 
Bowsers, Tannenbaum, Salas \& Volpe, 1995; Cannon-Bowers \& Salas, 1997; Klein, DeRouin \& Salas, 2006; Salas et al., 2008). Következésképpen az iskolában töltött évek során a tanulóknak el kell sajátítaniuk a csoportban történő problémamegoldás képességét (Neubert, Mainert, Kretzschmar \& Greiff, 2015). Ezzel összefüggésben az erre irányuló képesség fejlődését folyamatosan nyomon kell követnünk (Csapó, Lőrincz \& Molnár, 2012), a diagnosztizáláshoz pedig megfelelő mérőeszközökre van szükségünk.

Az elmúlt öt évben több kutatás is indult abból a célból, hogy hatékony mérőeszközt fejlesszen a kollaboratív problémamegoldó képesség egyén szintú vizsgálatára. Az ATC21S (Assessment \& Teaching of 21st Century Skills) projekt és az Educational Testing Service szakértői is célul tǔzték ki a konstruktum mérését, sőt, a kollaboratív problémamegoldó képesség 2015-ben a PISA-mérésben is helyet kapott (Griffin \& Care, 2015; OECD, 2013, 2017; Hao, Liu, von Davier, \& Kyllonen, 2017). Ennek ellenére egy hatékony, általánosan elfogadott mérőeljárás kialakításához számos további vizsgálatra lenne szükség, ugyanis több jelentős kutatásmódszertani probléma merült fel a képesség mérésével összefüggésben, mint például az adatok összehasonlíthatóságának vagy automatikus kódolásának problémája, amelyekre a mai napig pusztán „félmegoldásokkal” rendelkezünk (részletesen lásd Pásztor-Kovács, 2018; Pásztor-Kovács, Pásztor \& Molnár, 2018).

Az elsődleges problémát az okozza, hogy a kollaboratív problémamegoldás különálló konstruktumként való meghatározása meglehetősen újkeletú, a konstruktum nem rendelkezik szilárd elméleti alapokkal. A szakirodalomban négy modell ismeretes a képesség leírására (OECD, 2013; Hesse, Care, Buder, Sassenberg \& Griffin, 2015; Liu, Hao, von Davier, Kyllonen \& Zapata-Rivera, 2016; O’Neil, Chuang \& Chang, 2003; lásd PásztorKovács, 2015, 2018; Pásztor-Kovács, Pásztor \& Molnár, 2018), amelyek hasonlóságot mutatnak abból a szempontból, hogy két fő képességelemet, egy kollaboratív vagy szociális és egy problémamegoldó vagy kognitiv komponenst tartalmaznak. Eltérés mutatkozik azonban annak elképzelésében, hogy mely részképességek építik fel a két nagy komponenst, továbbá, hogy ezen részképességek hierarchikusan vagy mátrixban rendeződnek-e el. Nem volt olyan empirikus vizsgálat, amely bármelyik modell képességstruktúráját igazolta volna, így egyikről sem állíthattuk azt meggyőzően mostanáig, hogy az a leginkább lefedi a képességet.

A kollaboratív problémamegoldó képességet vizsgáló mérőeszközök módszertani terheltségét tekintve rendkívül hangsúlyos lenne azok érvényességének vizsgálata megfelelő külső validációs mérőeszközökkel. A problémamegoldó vagy kognitiv komponenst tekintve a validációs eljárás könnyedén kivitelezhető, a problémamegoldó gondolkodás mérésére ugyanis számos teszt áll rendelkezésünkre (OECD, 2017). A kollaboratív vagy szociális komponens különböző aspektusainak vizsgálatára is jelentős számú, elsősorban kvalitatív eljárás ismeretes (például Lewis, 2003; Smith-Jentsch, Cannon-Bowers, Tannenbaum \& Salas, 2008), a számunkra kívánatos feltételeknek azonban elenyésző mennyiségú mérőeszköz tesz eleget. Ezek az eszközök ugyanis egyrészt gyakran nem az egyént, hanem a teljes csoportot vizsgálják. Ha mégis az egyén kollaboratív képességei állnak a fókuszban, az értékelést egy külső megfigyelő vagy a csoporttársak végzik, kifejezetten egy adott csoportmunkával kapcsolatban (pl.: Lim \& Klein, 2006; Loughry, Ohland \& Moore, 2007). A megfelelő validációs eszközt ezzel szemben egy olyan mérőeszköz jelentené, amely az egyénről és nem a teljes csoportról ad viszszajelzést, továbbá az egyén kollaboratív képességeiről általánosságban mond ítéletet, nem egyetlen csoportmunka alapján, hiszen utóbbit több tényező is erőteljesen befolyásolhatja (a csoport tagjainak kognitív és szo ciális képességei, személyiségjegyei, továbbá a probléma jellege). Két olyan mérőeszközt találtunk mindössze, amelyek egyrészt általánosságban (és nem egy adott csoportmunkára vonatkozóan) reflektálnak az egyén kollaboratív képességeire, másrészt önértékelő skálák révén alkalmasak az egyén szintű adatgyūjtésre (Kasik, 2013; Cumming et al., 2015). Az említett mérőeszközök tartalmukat tekintve azonban nehezen összeegyeztet- 
hetőek a kollaboratív komponens azon megközelítéseivel, amelyet a kollaboratív problémamegoldó képességet leíró modellek nyújtanak.

\section{A kutatás célja}

Jelen tanulmány egy új, „Kollaboratív képességek” címet viselő önértékelő kérdőív fejlesztésének folyamatát, továbbá kipróbálásának eredményeit mutatja be. A kérdőív fejlesztése kettós célt szolgált. Egyrészt egy olyan, a kollaboratív problémamegoldó képességet leíró elméleti modellek egyikére épülő mérőeszközt kívántunk kialakítani, amely az egyén szintjén nyújt átfogó (és nem egyetlen esetre reflektáló) visszacsatolást a tanulók kollaborativ képességeiről, másrészt célunk volt a kollaboratív problémamegoldó képesség struktúrájának mélyebb megismerése azáltal, hogy az elméleti modellek egyikét empirikusan teszteljük.

Empirikus vizsgálatunkban az alábbi hipotéziseket teszteltük:

H1: A kérdőívvel megbízható becslés adható a tanulók kollaborativ képességeiröl (Cumming et al., 2015; Kasik, 2013).

H2: A megerősitő faktorelemzés eredménye igazolja a kollaborativ képességek vizsgálatának alapját képező elméleti modellt (Hesse et al., 2015).

\section{A mérőeszköz fejlesztése}

A mérőeszköz-fejlesztés folyamatának első lépéseként a kérdőív alapját jelentő elméleti keretrendszert kellett kiválasztanunk. Olyan kollaboratív problémamegoldó képességet leíró elméleti keretre volt szükségünk, amely megfelelő részletességgel mutatja be a kollaboratív komponenst. Ennek a célnak a négy létező modell közül (OECD, 2013; Hesse et al., 2015; Liu et al., 2016; O'Neil et al., 2003) az ATC21S projekt hierarchikus modellje (Hesse et al., 2015) felelt meg a leginkább, választásunk tehát erre az elméleti keretre esett (1. ábra). A projekt kutatói a kollaboratív problémamegoldó képességet kilenc szociális és kilenc kognitív részképesség halmazaként írták le. A kilenc kollaboratív vagy szociális részképesség a következők: cselekvés, interakció, erőfeszítés, adaptív válaszkészség, a viselkedés illesztése a társ igényeihez, tárgyalás, önértékelés, a társak értékelése, fele lősségvállalás. A részképességek három nagyobb képességelem, a részvétel, a nézőpontátvétel és a szociális szabályozás alá szerveződnek. Az 1. táblázat részletes leírást ad arról, hogy az elméletalkotók elképzelése szerint adott képességszinteken milyen teljesítmény jellemez egy tanulót adott szociális részképességre nézve (Hesse et al., 2015, p. 43). 


\begin{tabular}{|c|c|}
\hline \multicolumn{2}{|c|}{ Kollaboratív problémamegoldó képesség } \\
\hline Szociális képességek & Kognitív képességek \\
\hline Részvétel & Feladatszabályozás \\
\hline Cselekvés & Elemzés \\
\hline Interakció & Célállítás \\
\hline Erőfeszítés & Erőforrások menedzselése \\
\hline Nézőpontátvétel & Rugalmasság \\
\hline Adaptív válaszkészség & Információgyűjtés \\
\hline A viselkedés illesztése a társ igényeihez & Módszeresség \\
\hline Szociális szabályozás & Tanulás és tudásépítés \\
\hline $\begin{array}{c}\text { Tárgyalás } \\
\text { Önértékelés } \\
\text { A társak értékelése } \\
\text { Felelősségvállalás }\end{array}$ & $\begin{array}{c}\text { Összefüggés-elemzés } \\
\text { Ok-okozat kapcsolat felismerése } \\
\text { Hipotézisalkotás }\end{array}$ \\
\hline
\end{tabular}

1. ábra. Hesse és munkatársainak kollaboratív problémamegoldó képesség modellje (Hesse et al., 2015, pp. 41-52. alapján)

Minden részképességhez 4 tételt fejlesztettünk, közülük egy, legfeljebb kettő fordított értékelésű (2. táblázat). A kérdőív így összesen 36 tételt számlál, amelyből 15 fordított értékelésǔ. A Nézőpontátvétel képességét Hesse és munkatársai (2015) mindössze két részképességen keresztül definiálták, így ez az alskálánk lett a három közül a legrövidebb, 4-4 darab, összesen 8 állítást tartalmaz az Adaptív válaszkészség és A viselkedés illesztése a társ igényeihez részképességekkel összefüggésben. A Szociális szabályozás képességét ezzel szemben 4 részképesség írja le a modellben, így ehhez az alskálához rendeltük a legtöbb, összesen 16 tételt. $A$ harmadik, Részvétel alskála 12 tétellel vizsgálja a célkonstruktumot. Az önjellemzésre ötfokú skálát biztosítottunk, amelyen a tanulók azt tudták kifejezni a megfelelő számérték kiválasztásával, hogy a kérdőív adott állításai mi lyen mértékben igazak rájuk. 


\begin{tabular}{|c|c|c|c|c|}
\hline $\begin{array}{l}\text { Képesség/ } \\
\text { Részképesség }\end{array}$ & Indikátor & $\begin{array}{c}\text { Alacsonyan } \\
\text { fejlett }\end{array}$ & $\begin{array}{c}\text { Közepesen } \\
\text { fejlett }\end{array}$ & Magasan fejlett \\
\hline
\end{tabular}

\section{Részvétel (Participation)}

\begin{tabular}{|c|c|c|c|c|}
\hline Cselekvés (Action) & $\begin{array}{l}\text { Aktivitás a teszt } \\
\text { közben }\end{array}$ & $\begin{array}{l}\text { Aktivitás hiánya } \\
\text { vagy nagyon } \\
\text { alacsony szintje }\end{array}$ & $\begin{array}{l}\text { Aktivitás ismerős } \\
\text { kontextusban }\end{array}$ & $\begin{array}{l}\text { Aktivitás ismerős és } \\
\text { ismeretlen kontextusban }\end{array}$ \\
\hline $\begin{array}{l}\text { Interakció } \\
\text { (Interaction) }\end{array}$ & $\begin{array}{l}\text { Interakció a } \\
\text { csoporttagokkal, } \\
\text { kezdeményezés és } \\
\text { reakció a } \\
\text { csoporttársak } \\
\text { kezdeményezéseire }\end{array}$ & $\begin{array}{l}\text { A kommunikáció } \\
\text { nyugtázása direkt } \\
\text { vagy indirekt } \\
\text { módon }\end{array}$ & $\begin{array}{l}\text { Reakció a } \\
\text { megszólításokra }\end{array}$ & $\begin{array}{l}\text { Interakció vagy aktivitás } \\
\text { kezdeményezése és } \\
\text { bátorítása }\end{array}$ \\
\hline $\begin{array}{l}\text { Erőfeszítés } \\
\text { (Task completion) }\end{array}$ & $\begin{array}{l}\text { Feladat vagy } \\
\text { részfeladat vállalása } \\
\text { és kivitelezése }\end{array}$ & $\begin{array}{l}\text { Puszta jelenlét } \\
\text { erőfeszítés nélkül }\end{array}$ & $\begin{array}{l}\text { A feladat azonosítása } \\
\text { és kísérlet az } \\
\text { elvégzésére }\end{array}$ & $\begin{array}{l}\text { Kitartás a feladat } \\
\text { elvégzésében, többszöri } \\
\text { kísérlet, több stratégia } \\
\text { kipróbálása }\end{array}$ \\
\hline
\end{tabular}

\section{Nézőpontátvétel (Perspective taking)}

\begin{tabular}{|c|c|c|c|c|}
\hline $\begin{array}{l}\text { Adaptív } \\
\text { válaszkészség } \\
\text { (Adaptive } \\
\text { responsiveness) }\end{array}$ & $\begin{array}{l}\text { A csoporttagok } \\
\text { hozzájárulásának } \\
\text { ignorálása, } \\
\text { elfogadása vagy } \\
\text { adaptálása }\end{array}$ & $\begin{array}{l}\text { A csoporttagok } \\
\text { hozzájárulásának, } \\
\text { kezdeményezésé- } \\
\text { nek } \\
\text { figyelembevétele }\end{array}$ & $\begin{array}{l}\text { A csoporttagok } \\
\text { hozzájárulásának, } \\
\text { kezdeményezésének } \\
\text { adaptálása }\end{array}$ & $\begin{array}{l}\text { A csoporttagok } \\
\text { javaslatainak } \\
\text { felhasználása új } \\
\text { megoldási útvonalak } \\
\text { kidolgozásához }\end{array}$ \\
\hline $\begin{array}{l}\text { A viselkedés } \\
\text { illesztése a társ } \\
\text { igényeihez } \\
\text { (Audience } \\
\text { awareness) }\end{array}$ & $\begin{array}{l}\text { Annak a tudata, } \\
\text { hogy hogyan kell a } \\
\text { viselkedést úgy } \\
\text { alakítani, hogy a } \\
\text { csoporttársak } \\
\text { igényeihez } \\
\text { illeszkedjen }\end{array}$ & $\begin{array}{l}\text { A tevékenység } \\
\text { nincs a } \\
\text { csoporttársak } \\
\text { igényeihez } \\
\text { illesztve }\end{array}$ & $\begin{array}{l}\text { A tevékenység } \\
\text { módosul a } \\
\text { csoporttagok } \\
\text { visszajelzésének } \\
\text { függvényében }\end{array}$ & $\begin{array}{l}\text { A tevékenység a } \\
\text { csoporttagok } \\
\text { visszajelzéseinek } \\
\text { interpretációján alapul }\end{array}$ \\
\hline
\end{tabular}

\section{Szociális szabályozás (Social regulation)}

\begin{tabular}{|c|c|c|c|c|}
\hline $\begin{array}{l}\text { Tárgyalás } \\
\text { (Negotiation) }\end{array}$ & $\begin{array}{l}\text { Megoldás találása } \\
\text { vagy } \\
\text { kompromisszumra } \\
\text { jutás }\end{array}$ & $\begin{array}{l}\text { Megjegyzés az } \\
\text { eltérésekről }\end{array}$ & $\begin{array}{l}\text { Kísérlet a közös } \\
\text { álláspont } \\
\text { kialakítására }\end{array}$ & $\begin{array}{l}\text { Sikeres megoldása a } \\
\text { nézeteltérésnek }\end{array}$ \\
\hline $\begin{array}{l}\text { Önértékelés } \\
\text { (Self evaluation) }\end{array}$ & $\begin{array}{l}\text { A saját erősségek } \\
\text { és gyengeségek } \\
\text { felismerése }\end{array}$ & $\begin{array}{l}\text { Megjegyzés a saját } \\
\text { teljesítményről }\end{array}$ & $\begin{array}{l}\text { Megjegyzés a saját } \\
\text { teljesítményről } \\
\text { adekvátságára } \\
\text { vonatkozóan }\end{array}$ & $\begin{array}{l}\text { Következtetés } \\
\text { kompetenciára a saját } \\
\text { teljesítmény } \\
\text { függvényében }\end{array}$ \\
\hline $\begin{array}{l}\text { A társak értékelése } \\
\text { (Transactive } \\
\text { memory) }\end{array}$ & $\begin{array}{l}\text { A csoporttársak } \\
\text { erősségeinek és } \\
\text { gyengeségeinek } \\
\text { felismerése }\end{array}$ & $\begin{array}{l}\text { Megjegyzés a } \\
\text { társak } \\
\text { teljesítményéről }\end{array}$ & $\begin{array}{l}\text { Megjegyzés a társak } \\
\text { teljesítményéről } \\
\text { adekvátságukra } \\
\text { vonatkozóan }\end{array}$ & $\begin{array}{l}\text { A csoporttársak } \\
\text { teljesítményét figyelembe } \\
\text { véve javaslat feladat } \\
\text { kiosztására }\end{array}$ \\
\hline $\begin{array}{l}\text { Felelősség-vállalás } \\
\text { (Responsibility } \\
\text { initiative) }\end{array}$ & $\begin{array}{l}\text { Felelősségvállalás } \\
\text { azért, hogy a } \\
\text { csoport teljesítse a } \\
\text { feladatát }\end{array}$ & $\begin{array}{l}\text { A csoporttagoktól } \\
\text { javarészt független } \\
\text { aktivitás }\end{array}$ & $\begin{array}{l}\text { A feladatok } \\
\text { elvégzése, és erről } \\
\text { visszajelzés nyújtása } \\
\text { a csoporttagoknak }\end{array}$ & $\begin{array}{l}\text { Felelősségvállalás a } \\
\text { csoport munkájáért, } \\
\text { amelyet a többes szám } \\
\text { első személyben } \\
\text { megfogalmazott üzenetek } \\
\text { is jeleznek }\end{array}$ \\
\hline
\end{tabular}




\begin{tabular}{|c|c|c|c|}
\hline Alskála & Részképesség & $\begin{array}{c}\text { Tétel } \\
- \\
\text { szám }\end{array}$ & $\begin{array}{c}\text { Példatétel } \\
\text { Amikor csoportban dolgozunk }\end{array}$ \\
\hline \multirow{3}{*}{ Részvétel } & Cselekvés & 4 & ha tehetem, általában háttérbe vonulok. (fordított tétel) \\
\hline & Interakció & 4 & $\begin{array}{l}\text { reagálok a többiek felvetéseire (pl.: helyesléssel, kérdéssel } \\
\text { stb.). }\end{array}$ \\
\hline & Erőfeszítés & 4 & a rám bízott feladatot mindenképpen megcsinálom. \\
\hline \multirow{3}{*}{$\begin{array}{l}\text { Nézőpont- } \\
\text { átvétel }\end{array}$} & Adaptív válaszkészség & 4 & sokszor továbbfejlesztem egy-egy társam ötletét. \\
\hline & $\begin{array}{l}\text { A viselkedés illesztése a } \\
\text { társ igényeihez }\end{array}$ & 4 & $\begin{array}{l}\text { képes vagyok úgy elmagyarázni az ötleteimet, hogy azt } \\
\text { mindenki megértse. }\end{array}$ \\
\hline & Tárgyalás & 4 & $\begin{array}{l}\text { fontos számomra, hogy a végén nekem legyen igazam. } \\
\text { (fordított tétel) }\end{array}$ \\
\hline \multirow{3}{*}{$\begin{array}{l}\text { Szociális } \\
\text { szabályozás }\end{array}$} & Önértékelés & 4 & $\begin{array}{l}\text { szólok, ha menet közben úgy érzem, hogy valami más } \\
\text { részmunkát hatékonyabban tudnék végezni. }\end{array}$ \\
\hline & A társak értékelése & 4 & $\begin{array}{l}\text { jelzem, ha szerintem változtatni kellene a } \\
\text { munkamegosztáson. }\end{array}$ \\
\hline & Felelősségvállalás & 4 & $\begin{array}{l}\text { a siker érdekében a saját dolgom végeztével szívesen segítek } \\
\text { a társaimnak. }\end{array}$ \\
\hline
\end{tabular}

2. táblázat. Példatételek a kollaboratív képességeket vizsgáló kérdőivből a kérdőív alskáláival és az ahhoz tartozó részképességekkel összefüggésben

\section{Empirikus vizsgálat}

\section{Módszerek}

A kérdőívet először egy papíralapú pilotvizsgálatban próbáltuk ki 96 nyolcadik évfolyamos tanuló részvételével (lásd Pásztor-Kovács, 2018). A tanulmány fókuszában álló online nagymintás adatfelvételben már a pilotkutatás eredményei alapján továbbfejlesztett kérdőívváltozatot alkalmaztuk. Az adatfelvétel egy OTKA kutatás keretein belül 2017. január és június között kivitelezett „Gondolkodási képességek átfogó mérése” című nagyszabású online mérés részeként zajlott le az eDia rendszeren keresztül (Molnár, 2015; Molnár \& Csapó, 2018; Molnár, Makay \& Ancsin, 2018). A kutatásban való részvétel önkéntes volt, a felkérés az eDia-rendszer partneriskoláinak került kiküldésére. A tág életkori intervallumban megvalósuló adatfelvételben a „Kollaboratív kérdőív"-et kitöltő nyolcadik évfolyamos diákok összességében négy tanórányi tesztet oldottak meg. A tesztekben feltérképezésre került induktív gondolkodásuk, vizuális memóriájuk, interaktív problémamegoldó képességük, kombinatív gondolkodásuk, kreativitásuk és internetes információkeresési hatékonyságuk fejlettségi szintje, továbbá tanulási stratégiáik. Az egy tanórára vonatkozó tesztcsomagban, amely kérdőívünket tartalmazta, a tanulóknak először egy 14 itemes vizuális memória tesztet, majd egy 6 itemes divergens gondolkodás (kreativitás) tesztet kellett megoldaniuk. Ezek után egy 45 tételből álló demográfiai adatokra vonatkozó háttérkérdőív, majd a kollaboratív képességeket mérő kérdőív tételei következtek. A kollaboratív kérdőívet tartalmazó tesztcsomagot az ország egész területéről 65 iskola 1613 nyolcadik évfolyamos tanulója oldotta meg. Az eredmények elemzése során ugyanakkor jelentős adatvesztéssel szembesültünk, a tanulók mintegy fele, 871 tanuló adott csupán minden kérdőívtételre választ. Az adatok elemzése és az eredmények bemutatása a továbbiakban erre a 871 fős mintára vonatkozik, amelyben a tanulók átlagos életkora $M=14,54$ év (SD=0,45; 
N=805; 65 föről nincs adatunk az életkorra vonatkozóan), 44,9\%-uk fiú, 54,2\%-a lány, a minta 0,9\%-a nem adta meg a nemét.

A kérdőívtételek sorban egymás alatt helyezkedtek el, egy oldalon összesen 4-6 állítás szerepelt. A megfelelő választ rádiógomb segítségével kellett megadniuk a diákoknak. A rádiógombok az ötfokú skálának megfe lelően öt oszlopban helyezkedtek el, az oszlophoz tartozó válaszok (pl.: Teljes mértékben jellemző rám) az oszlopok tetején voltak olvashatóak (2. ábra). Az adatelemzéshez az Mplus 6.11 és az SPSS 21 statisztikai progra mokat alkalmaztuk.

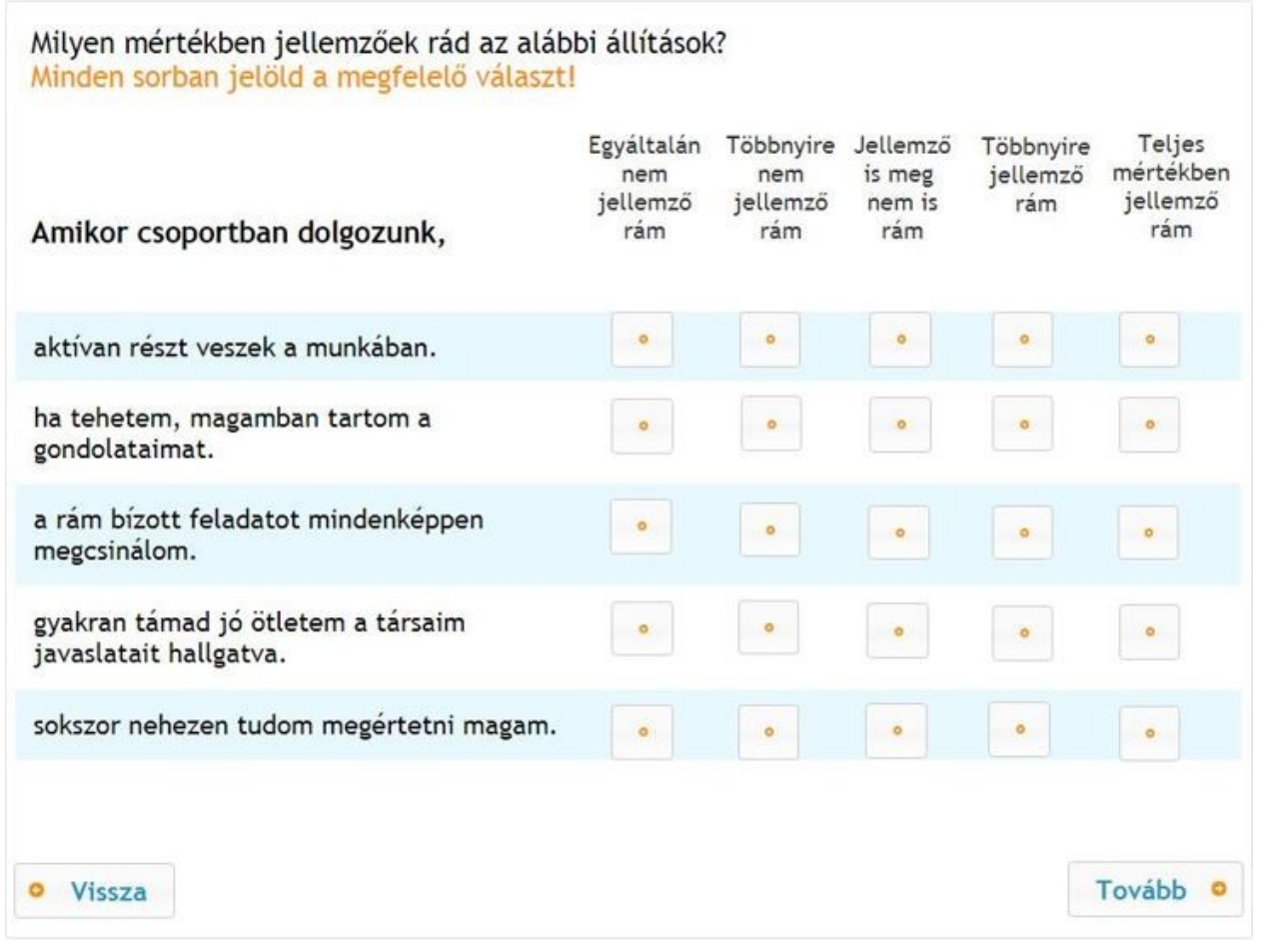

2. ábra. Részlet az eDia-rendszerben futó „Kollaboratív képességek” kérdőivből

\section{Eredmények}

Elsőként a 36 tételes kérdőív megbízhatóságát teszteltük. A teljes skála reliabilitása kellően magas volt (Cronbach- $\alpha=0,90$, lásd a 4. táblázatot). A Részvétel (Cronbach- $\alpha=0,85)$ és a Szociális szabályozás (Cronbach$a=0,76$ ) alskálák megbízhatóságát is megfelelőnek találtuk. A 8 állítást tartalmazó Nézőpontátvétel alskála re liabilitása (Cronbach- $\alpha=0,67)$ még az elfogadható tartományban mozgott, a részképességeket mérő tételegyüttesek közül viszont több is kifejezetten alacsony reliabilitást mutatott.

Megvizsgáltuk, hogy a 0,6 alatti Cronbach-a értéket felvevő, adott részképességet vizsgáló tételkészletek állításai között van-e olyan, amelynek törlése javítaná az eredmények megbízhatóságát. A Tárgyalás és az Interakció részképességek esetében találtunk csak egy-egy ilyen tételt, ezeket a további elemzésekből kizártuk.

Az elméleti modell validálásának céljából végzett megerősítő faktorelemzést így 34 tétel vizsgálatával kezdtük meg. Először a részképességek számának megfelelően a kilencdimenziós modell tesztelését végeztük el az Mplus programban. A megerősítő faktorelemzések esetében a modell illeszkedését a TLI (Tucker-Lewis Index), a CFI (Comparative Fit Index), valamint az RMSEA (Root Mean Square Error of Approximation) mutatókon keresztül szükséges megvizsgálni. A TLI és a CFI-indexek esetében 0,9 fölötti, az RMSEA-index esetében pedig 0,08 
alatti érték indikálja a modell helytállóságát. A kilencdimenziós modell mutatói alacsonyak voltak, tételredukcióra volt szükség a megfelelő illeszkedés kialakítására. Összesen 12 tételt távolítottunk el a 34-ből, mindig a legalacsonyabb faktorsúllyal rendelkezőt. A mutatók folyamatosan javultak, de még mindig nem érték el a kívánatos értékeket $\left(\chi^{2}=1223,07 ; \mathrm{df}=215 ; p<0,01 ; \mathrm{CFI}=0,877 ; \mathrm{TLI}=0,842 ; \mathrm{RMSEA}=0,073\right)$. A következő legalacsonyabb faktorsúlyú tétel eltávolításával a Tárgyalás faktoron már csak egy állítás maradt volna, ezért az elemzést ezen a ponton nem folytattuk tovább, a kilencdimenziós modellt elvetettük.

\begin{tabular}{|c|c|c|c|c|}
\hline Skála & Tételszám & $\begin{array}{c}\text { Cronbach- } \\
\alpha\end{array}$ & $\begin{array}{c}\text { Összevont } \\
\text { pontérték átlaga és } \\
\text { szórása }\end{array}$ & $\begin{array}{c}\text { A skála elméleti } \\
\text { minimuma-maximuma }\end{array}$ \\
\hline Teljes skála & 36 & 0,90 & $130,51(17,77)$ & $36-180$ \\
\hline Részvétel & 12 & 0,85 & $45,20(7,50)$ & $12-60$ \\
\hline Cselekvés & 4 & 0,75 & $14,99(3,11)$ & \multirow{3}{*}{$4-20$} \\
\hline Interakció & 4 & 0,60 & $14,62(2,72)$ & \\
\hline Erőfeszítés & 4 & 0,74 & $15,55(3,04)$ & \\
\hline Nézőpontátvétel & 8 & 0,67 & $28,61(4,46)$ & $8-40$ \\
\hline $\begin{array}{l}\text { Adaptív } \\
\text { válaszkészség }\end{array}$ & 4 & 0,49 & $13,95(2,49)$ & \multirow[b]{2}{*}{$4-20$} \\
\hline $\begin{array}{l}\text { A viselkedés } \\
\text { illesztése a társ } \\
\text { igényeihez }\end{array}$ & 4 & 0,62 & $14,66(2,85)$ & \\
\hline $\begin{array}{l}\text { Szociális } \\
\text { szabályozás }\end{array}$ & 16 & 0,76 & $56,74(7,89)$ & $16-80$ \\
\hline Tárgyalás & 4 & 0,26 & $13,78(2,44)$ & \multirow{4}{*}{$4-20$} \\
\hline Önértékelés & 4 & 0,45 & $14,05(2,61)$ & \\
\hline A társak értékelése & 4 & 0,56 & $13,50(2,89)$ & \\
\hline Felelősségvállalás & 4 & 0,66 & $15,41(2,82)$ & \\
\hline
\end{tabular}

3. táblázat. A kérdő́n pszichometriai mutatói

Ezek után a háromdimenziós modell illeszkedését teszteltük a képességek számának megfelelően. A mutatók ezúttal is meglehetősen gyengék voltak 34 tétel bevonásakor, ezért a faktorsúlyok figyelembevételével ismét megkezdtük az állítások szelektálását. 17 tétel kizárása után a maradék 17 egy elfogadható illeszkedésű struktúrát alakított ki, a tételek faktorsúlyai minden esetben 0,5 fölötti értéket vettek fel $\left(\chi^{2}=386,06 \mathrm{df}=116\right.$; $\mathrm{p}<0,01 ; \mathrm{CFI}=0,918 ; \mathrm{TLI}=0,904 ; \mathrm{RMSEA}=0,052)$. A 17 tételes változókészletet az egydimenziós modellel összefüggésben is megvizsgáltuk. Az illeszkedésmutatók értéke a módosított modell vonatkozásában $\left(\chi^{2}=469,86\right.$ $\mathrm{df}=119 ; \mathrm{p}<0,01 ; \mathrm{CFI}=0,894 ; \mathrm{TLI}=0,879 ; \mathrm{RMSEA}=0,058)$ szignifikánsan alacsonyabb lett $\left(\chi^{2}=97,218 \mathrm{df}=3\right.$; $p<0,01)$.

Annak vizsgálatára, hogy a három faktor milyen mértékben határozza meg a kollaboratív képességek látens konstruktumát, hierarchikus faktorelemzést végeztünk (3. ábra). 


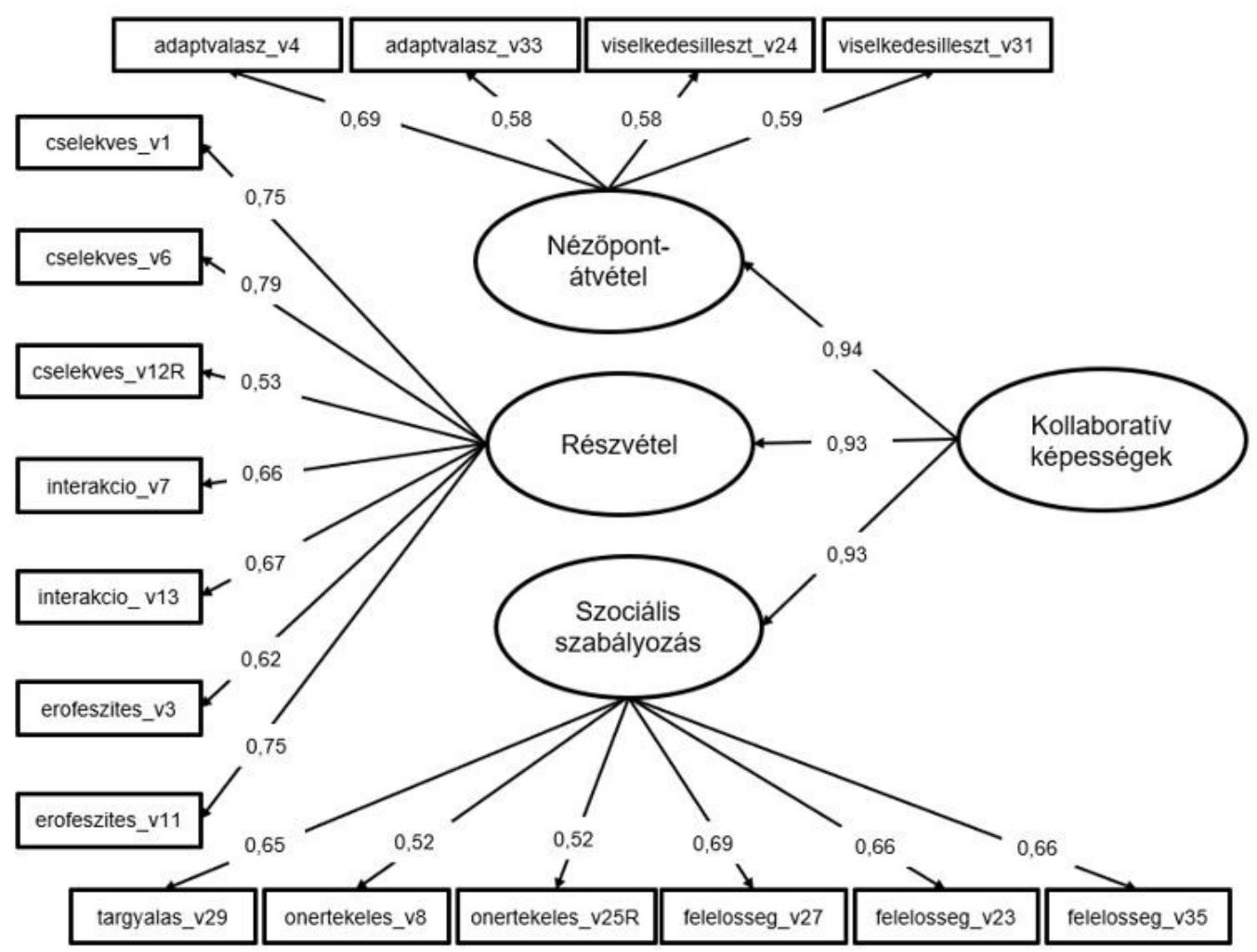

3. ábra. A kérdőív 17 tételén végzett hierarchikus faktorelemzés eredménye (Megj: : A számértékek a nyilakon a faktorsúlyokat jelölik.)

Az eredmények alapján megállapítható, hogy a három faktor közel egyenlő mértékben határozza meg a látens kollaboratív konstruktumot, méghozzá kifejezetten magas, 0,9 fölötti faktorsúllyal. A magas értékek arra utalnak, hogy habár némileg gyengébben illeszkedik az egydimenziós modell változókészletünkhöz, erős a létjogosultsága az egydimenziós konstruktum feltételezésének.

A rövidített, 17 tételes skálán (4. táblázat) a részképességeket vizsgáló állítások mindegyikéből megtalálható egy, az eredeti elméleti modellt tehát legalább egy tétel a redukált kérdőívben is őrzi. Az egyetlen kivételt a Társak értékelése részképesség jelenti, a faktorelemzés során az ehhez a részképességhez tartozó összes állítást szelektálnunk kellett. A kizárt tételek nagy része (a 17-ből 14) fordított értékelésű volt, azaz feltételezhető, hogy a tanulóknak nehézséget okozott ezen állítások értelmezése, megítélése. 


\begin{tabular}{|c|c|}
\hline Tétel & Amikor csoportban dolgozunk, \\
\hline cselekves_1_v1 & aktívan részt veszek a munkában. \\
\hline cselekves_2_v6 & szeretek tevékeny lenni. \\
\hline cselekves_3_v12_R & ha tehetem, inkább a többiekre bízom a dolgot. \\
\hline interakcio_2_v7 & reagálok a többiek felvetéseire, javaslataira (pl.: helyesléssel, kérdéssel stb.). \\
\hline interakcio_3_v13 & ötleteimet, gondolataimat megosztom a társakkal. \\
\hline erofeszites_1_v3 & a rám bízott feladatot mindenképpen megcsinálom. \\
\hline erofeszites_2_v11 & szívesen vállalok valamilyen feladatot. \\
\hline adaptvalasz_1_v4 & gyakran támad jó ötletem a társaim javaslatait hallgatva. \\
\hline adaptvalasz_4_v33 & sokszor továbbfejlesztem egy-egy társam ötletét. \\
\hline viselkedesilleszt_3_v24 & általában mindenkivel megtalálom a közös hangot. \\
\hline viselkedesilleszt_4_v31 & képes vagyok úgy elmagyarázni az ötleteimet, hogy azt mindenki megértse. \\
\hline targyalas_3_v29 & mindig igyekszem egyetértést kialakítani a csoportban, mielőtt valamiről döntenénk. \\
\hline onertekeles_1_v8 & végiggondolom, hogy milyen munkára vagyok a legalkalmasabb. \\
\hline onertekeles_3_v25 & $\begin{array}{l}\text { szólok, ha menet közben úgy érzem, hogy valami más részmunkát hatékonyabban } \\
\text { tudnék végezni. }\end{array}$ \\
\hline felelosseg_2_v23 & felelősnek érzem magam azért, hogy eljussunk a kitűzött célig. \\
\hline felelosseg_3_v27 & a siker érdekében a saját dolgom végeztével gyakran segítek a társaimnak. \\
\hline felelosseg_4_v35 & fontosnak tartom, hogy a csoportban mindenki a legjobbat hozza ki magából. \\
\hline
\end{tabular}

Megvizsgáltuk az új, 17 állításból álló skála pszichometriai mutatóit. Az új változókészlet mögötti 3 faktor átlagait az 5. táblázatban közöljük.

\begin{tabular}{lcccc}
\multicolumn{1}{c}{ Skála } & Tételszám & Cronbach $-\alpha$ & $\begin{array}{c}\text { Összevont } \\
\text { pontérték átlaga } \\
\text { és szórása }\end{array}$ & $\begin{array}{c}\text { A skála elméleti } \\
\text { minimuma- } \\
\text { Teljes skála }\end{array}$ \\
Részvétel & 17 & 0,91 & $64,40(10,39)$ & $17-105$ \\
Nézőpontátvétel & 7 & 0,85 & $27,09(4,81)$ & $7-35$ \\
Szociális szabályozás & 4 & 0,70 & $14,79(2,69)$ & $4-20$
\end{tabular}

5. táblázat. A 17 tétel mögötti három faktor átlaga és szórása

A faktorok alá tartozó tételek ismét három alskálát eredményeznek, ezek, valamint a teljes skála pszicho metriai mutatóit a 6. táblázatban foglaltuk össze. A tételredukció a 36 állítást tartalmazó kérdőív mutatóihoz képest mind a teljes skála, mind az alskálák esetében javított a megbízhatósági mutatókon, még a 4 tételes al skálára vonatkozó megbízhatósági mutató (Cronbach- $a=0,70$ ) értéke is elfogadható. 


\begin{tabular}{|c|c|c|c|c|c|}
\hline \multirow[b]{2}{*}{ Tétel } & \multicolumn{5}{|c|}{ A válaszok gyakoriságának eloszlása (\%) } \\
\hline & $\begin{array}{c}\text { Egyáltalán } \\
\text { nem } \\
\text { jellemző } \\
\text { rám }\end{array}$ & $\begin{array}{c}\text { Többnyire } \\
\text { nem } \\
\text { jellemző } \\
\text { rám }\end{array}$ & $\begin{array}{l}\text { Jellemzö is, } \\
\text { meg nem is }\end{array}$ & $\begin{array}{c}\text { Többnyire } \\
\text { jellemző } \\
\text { rám }\end{array}$ & $\begin{array}{c}\text { Teljes } \\
\text { mértékben } \\
\text { jellemző } \\
\text { rám }\end{array}$ \\
\hline cselekves_1_v1 & 1,1 & 2,3 & 23,1 & 45,5 & 28,0 \\
\hline cselekves_2_v6 & 3,2 & 7,7 & 27,4 & 38,6 & 23,1 \\
\hline cselekves_3_v12_R & 4,8 & 10,8 & 26,3 & 37,2 & 20,9 \\
\hline interakcio_2_v7 & 2,1 & 4,9 & 18,7 & 47,3 & 27,0 \\
\hline interakcio_3_v13 & 1,6 & 5,6 & 20,0 & 44,8 & 28,0 \\
\hline erofeszites_1_v3 & 0,7 & 2,2 & 15,1 & 37,3 & 44,7 \\
\hline erofeszites_2_v11 & 2,5 & 6,9 & 27,2 & 39,5 & 23,9 \\
\hline adaptvalasz_1_v4 & 2,5 & 5,2 & 26,1 & 45,2 & 21,0 \\
\hline adaptvalasz_4_v33 & 3,6 & 10,5 & 34,8 & 38,6 & 12,5 \\
\hline viselkedesilleszt_3_v24 & 1,7 & 5,0 & 24,1 & 43,7 & 25,5 \\
\hline viselkedesilleszt_4_v31 & 2,0 & 6,2 & 31,8 & 40,7 & 19,3 \\
\hline targyalas_3_v29 & 2,9 & 6,1 & 31,8 & 38,2 & 21,0 \\
\hline onertekeles_1_v8 & 2,8 & 6,1 & 20,3 & 42,0 & 28,8 \\
\hline onertekeles_3_v25 & 4,8 & 11,4 & 31,7 & 37,5 & 14,6 \\
\hline felelosseg_2_v23 & 2,5 & 6,3 & 23,2 & 37,7 & 30,3 \\
\hline felelosseg_3_v27 & 2,0 & 5,3 & 26,8 & 41,4 & 24,5 \\
\hline felelosseg_4_v35 & 3,2 & 6,7 & 25,0 & 34,6 & 30,5 \\
\hline
\end{tabular}

6. táblázat. A 17 tételes skála és három alskálájának pszichometriai mutatói

Önértékelő kérdőívünkben rangskálát alkalmaztunk, azaz a tételek aggregálása, átlagértékek közlése az alskálákkal kapcsolatban a statisztikai elveket szigorúan követve nem lenne lehetséges. A tendenciák szemléltetése végett kezeltük intervallumskálaként az így nyert változók összevont értékeit (erre vonatkozóan I. Józsa, 1999), ugyanakkor a 7. táblázatban mind a 17 tétellel kapcsolatban közöltük a válaszgyakoriságok százalékos értékeit.

Akár a faktorátlagokat, akár az alskálákon vagy a teljes skálán elért összevont pontértékek átlagát tekintjük, megállapítható, hogy a tanulók meglehetősen magasnak értékelték kollaborativ képességeik szintjét. Ezzel öszszefüggésben mind a teljes skála, mind a három alskála eloszlásgörbéi jobb oldali aszimmetriát mutatnak (4-7. ábra). 


\begin{tabular}{|c|c|c|c|c|c|}
\hline \multirow[b]{2}{*}{ Tétel } & \multicolumn{5}{|c|}{ A válaszok gyakoriságának eloszlása (\%) } \\
\hline & $\begin{array}{c}\text { Egyáltalán } \\
\text { nem } \\
\text { jellemző } \\
\text { rám }\end{array}$ & $\begin{array}{c}\text { Többnyire } \\
\text { nem } \\
\text { jellemző } \\
\text { rám }\end{array}$ & $\begin{array}{l}\text { Jellemzó is, } \\
\text { meg nem is }\end{array}$ & $\begin{array}{c}\text { Többnyire } \\
\text { jellemző } \\
\text { rám }\end{array}$ & $\begin{array}{c}\text { Teljes } \\
\text { mértékben } \\
\text { jellemzó } \\
\text { rám }\end{array}$ \\
\hline cselekves_1_v1 & 1,1 & 2,3 & 23,1 & 45,5 & 28,0 \\
\hline cselekves_2_v6 & 3,2 & 7,7 & 27,4 & 38,6 & 23,1 \\
\hline cselekves_3_v12_R & 4,8 & 10,8 & 26,3 & 37,2 & 20,9 \\
\hline interakcio_2_v7 & 2,1 & 4,9 & 18,7 & 47,3 & 27,0 \\
\hline interakcio_3_v13 & 1,6 & 5,6 & 20,0 & 44,8 & 28,0 \\
\hline erofeszites_1_v3 & 0,7 & 2,2 & 15,1 & 37,3 & 44,7 \\
\hline erofeszites_2_v11 & 2,5 & 6,9 & 27,2 & 39,5 & 23,9 \\
\hline adaptvalasz_1_v4 & 2,5 & 5,2 & 26,1 & 45,2 & 21,0 \\
\hline adaptvalasz_4_v33 & 3,6 & 10,5 & 34,8 & 38,6 & 12,5 \\
\hline viselkedesilleszt_3_v24 & 1,7 & 5,0 & 24,1 & 43,7 & 25,5 \\
\hline viselkedesilleszt_4_v31 & 2,0 & 6,2 & 31,8 & 40,7 & 19,3 \\
\hline targyalas_3_v29 & 2,9 & 6,1 & 31,8 & 38,2 & 21,0 \\
\hline onertekeles_1_v8 & 2,8 & 6,1 & 20,3 & 42,0 & 28,8 \\
\hline onertekeles_3_v25 & 4,8 & 11,4 & 31,7 & 37,5 & 14,6 \\
\hline felelosseg_2_v23 & 2,5 & 6,3 & 23,2 & 37,7 & 30,3 \\
\hline felelosseg_3_v27 & 2,0 & 5,3 & 26,8 & 41,4 & 24,5 \\
\hline felelosseg_4_v35 & 3,2 & 6,7 & 25,0 & 34,6 & 30,5 \\
\hline
\end{tabular}

7. táblázat. A nagymintás vizsgálatban alkalmazott kérdőív megerősitő faktorelemzés után megmaradt 17 tételére adott válaszok gyakorisága

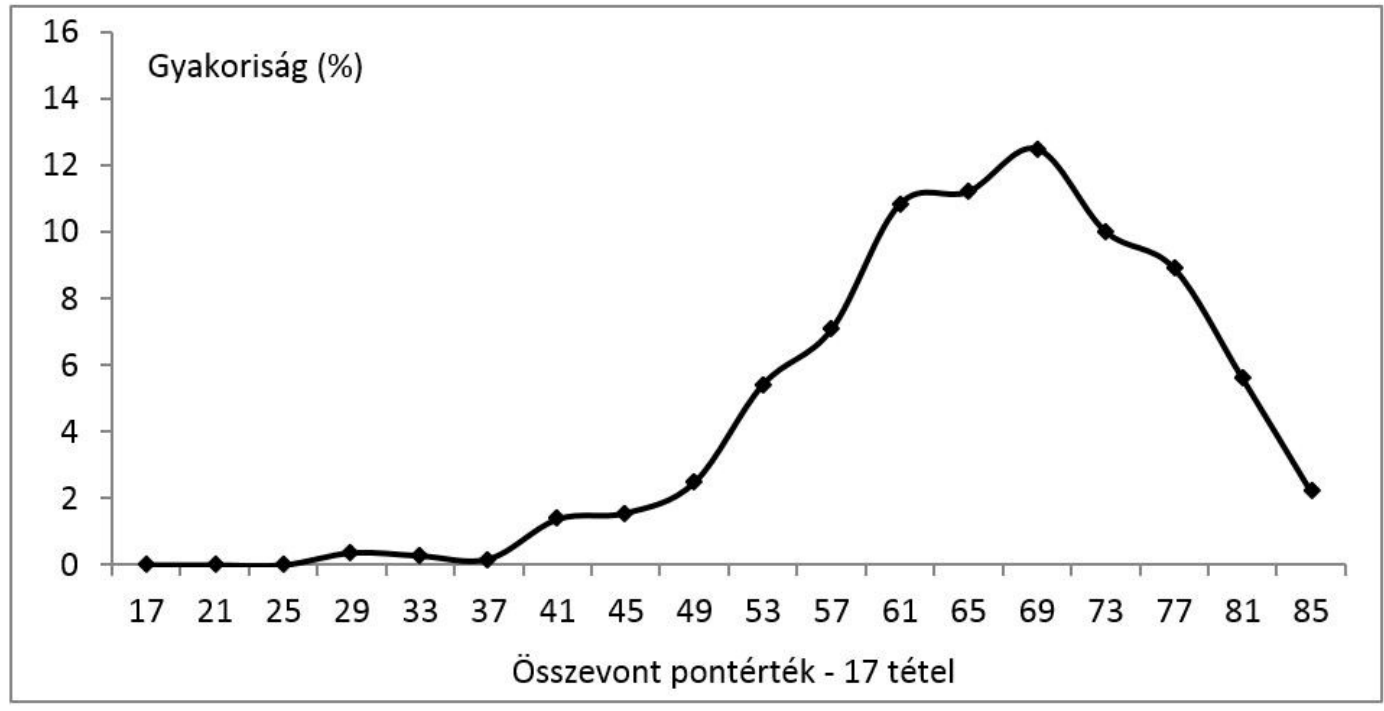

4. ábra. A 17 tételes skálán elért összevont pontértékek gyakorisági eloszlása 


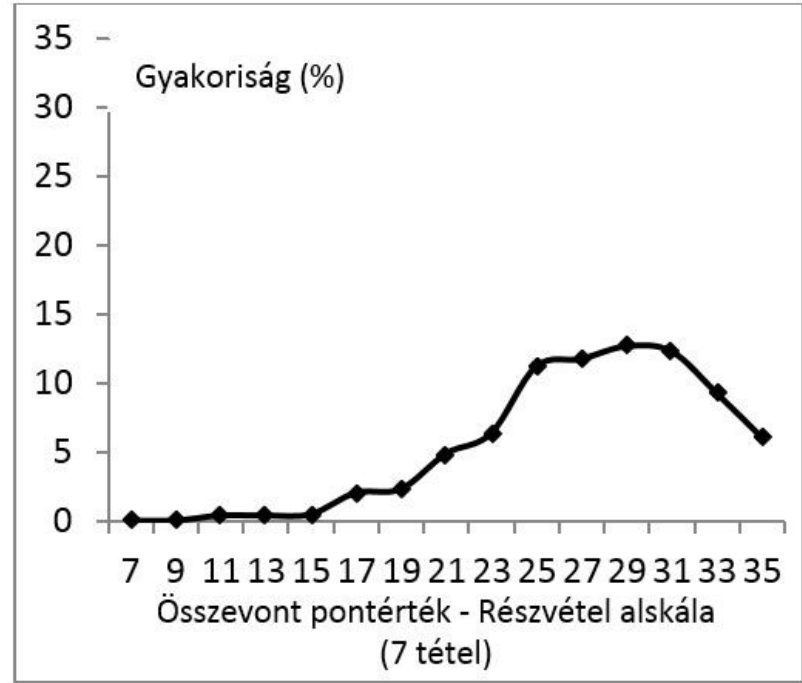

5. ábra. A Részvétel alskálán elért összevont pontértékek gyakorisági eloszlása

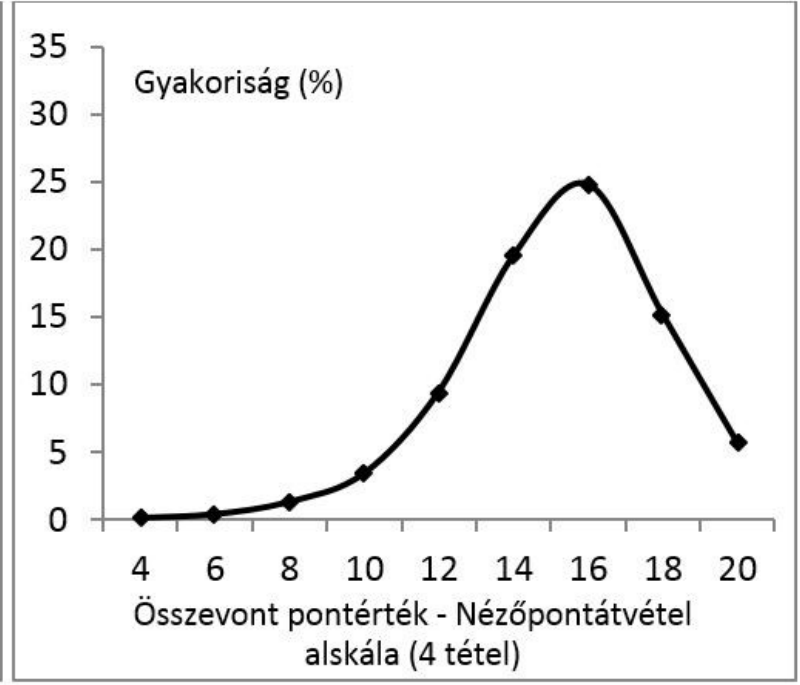

6. ábra. A Nézőpontátvétel alskálán elért összevont pontértékek gyakorisági eloszlása

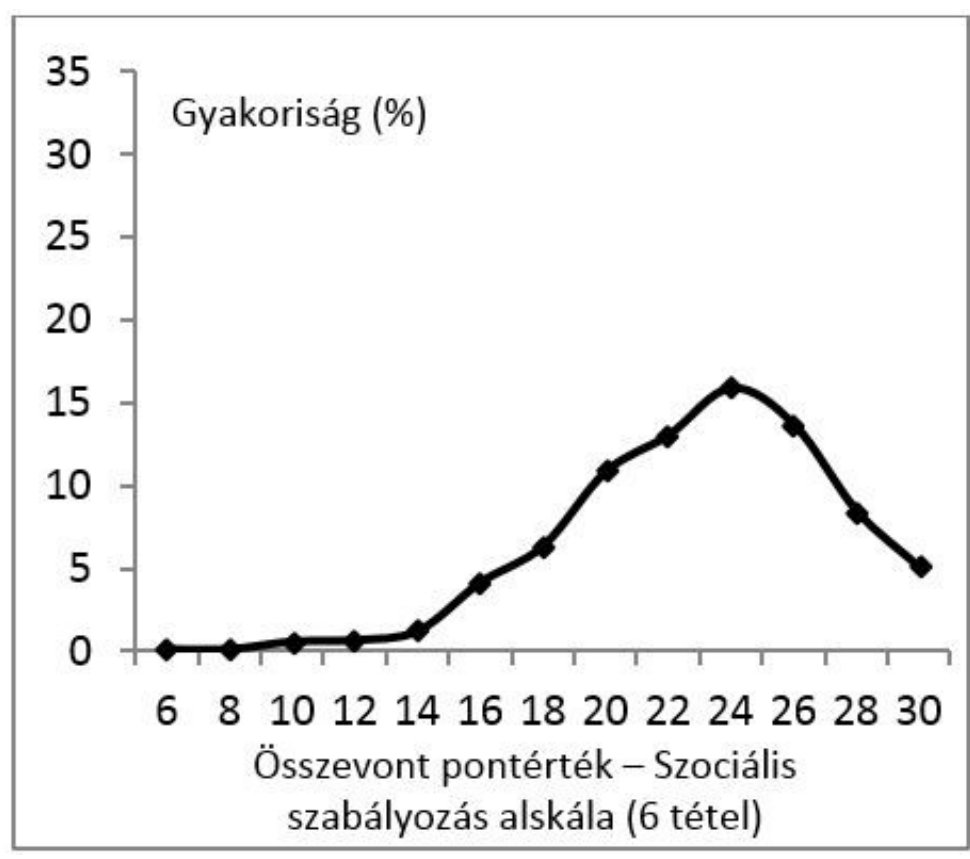

7. ábra. A Szociális szabályozás alskálán elért összevont pontértékek gyakorisági eloszlása

A teljes skála magas korrelációt mutatott mindhárom alskálával ( $r=0,84-0,92$; lásd a 8. táblázatot). Az alskálák ennél mérsékeltebb, de szintén magas együttjárást mutatnak ( $r=0,67-0,71)$. Az összefüggések jól visszaadják a megerősítő faktorelemzés tapasztalatait, azaz hogy nehezen eldönthető, hogy a konstruktumot egy- vagy háromdimenziósnak érdemes inkább tekintenünk. 


\begin{tabular}{|l|ccc|}
\multicolumn{1}{c|}{ Skála } & Teljes skála & Részvétel & Nézőpontátvétel \\
\hline Részvétel & 0,92 & \\
\hline Nézőpontátvétel & 0,84 & 0,67 \\
\hline Szociális szabályozás & 0,90 & 0,71 & 0,66 \\
\hline & 8. táblázat. A 17 tételes teljes skála és az alskálák közötti korrelációs együtthatók. \\
& \multicolumn{4}{r}{ Megj.: Minden korrelációsegyüttható $p<0,01$}
\end{tabular}

\section{Konklúzió}

A tanulmányban bemutatott kutatás célja egy olyan, a kollaborativ problémamegoldó képességet leíró elméleti modellek egyikére épülő mérőeszköz kialakítása volt, amely az egyén szintjén nyújt átfogó (és nem egyetlen esetre reflektáló) visszacsatolást a tanulók kollaboratív képességeirôl. Célunk volt továbbá a kollaboratív problémamegoldó képesség struktúrájának mélyebb megismerése azáltal, hogy az elméleti modellek egyikét empirikusan teszteljük.

Empirikus vizsgálatunk első hipotézise (H1: A kérdőívvel megbízható becslés adható a tanulók kollaborativ képességeiről) igazolást nyert. A megerősítő faktoranalízis segítségével kialakított 17 tételes rövidített skála és annak alskálái megfelelő, még a 4 állítást tartalmazó Nézőpontváltás alskála is elfogadható szintű reliabilitás mu tatókkal rendelkezik, a Kollaboratív képességek kérdőívet tehát megbízható mérőeszköznek tekinthetjük.

Második hipotézisünk (H2: A megerősitő faktorelemzés eredménye igazolja a kollaborativ képességek vizsgálatának alapját képező elméleti modellt) részben bizonyult helytállónak. Az ACT21S projekt elméleti modelljében szereplő három fő képesség kimutatható volt a kollaboratív komponens mögött, a részképességek azonban csak egy-egy tétel szintjén jelentek meg a 17 tételes változókészletben, faktor szintjén nem.

Az egyetlen kivételt $A$ társak értékelése részképesség jelentette. Ez az eredmény mindenképpen további vizsgálatra szorul. Érdemes lehet jövőbeli kutatásainkban egy-egy a részképességre vonatkozó tételt visszaemelni, és újfent ellenőrizni, hogy van-e helye a Szociális szabályozás faktoron. Jelenlegi hipotézisünk a gyenge illeszkedéssel kapcsolatban az, hogy míg az összes többi részképesség az egyén saját viselkedésére, tevékenységeire, attitúdjeire irányul a csoportos munkavégzéssel kapcsolatosan, A társak értékelése részképesség az „én” helyett az „ők” szabályozására irányul, amely mintha közelebb állna a vezetői képességek konstruktumához.

Az egy-, három- és kilencdimenziós modellek közül a háromdimenziós modell bizonyult a legalkalmasabbnak a konstruktum leírására. Bár a modell szignifikánsan jobban illeszkedett az adatokhoz, a hierarchikus faktorelemzés, továbbá a korrelációs elemzések eredményei is arra utaltak, hogy a három dimenzió szorosan öszszefügg egymással. A konstruktum egy vagy több dimenziós voltának kérdése továbbra is nyitottnak tekinthető, további kutatások szükségesek a helyzet egyértelmúsítésére.

A kérdőívet kitöltó tanulók meglehetősen magasra értékelték kollaboratív képességeiket. Ez a tendencia egybecseng az OECD azon adataival, amelyeket a 2015-ös PISA-mérésen kiközvetített háttérkérdőívvel gyűjtöttek a tanulókról a kollaboratív problémamegoldó képesség mérése után (OECD, 2017). A 15 éves diákoknak 8 darab, a kollaboráció iránti attitűdöket vizsgáló állításról kellett eldönteniük, hogy mennyire értenek vele egyet (A lehetséges válaszok: Teljes mértékben egyet értek - Egyetértek - Nem értek egyet - Egyáltalán nem értek egyet). A 8 tétel közül 3 a kérdőívünkhöz hasonló megfogalmazású, önértékelést előíró állítás volt. A min ta átlagosan 87\%-a egyetértett vagy teljes mértékben egyetértett a „Jó hallgatóság vagyok ( am a good listener)" állítással. A „Figyelembe veszem a többiek érdeklődését (I take into account what others are interested in)” 
állításra nézve ez az érték 86\%, a „Szívesen megfontolok más nézőpontokat ( enjoy considering different perspectives)" állítás esetében pedig $87 \%$. Azt, hogy a tanulók önmagukról alkotott véleménye mennyire találkozik a realitással, további kutatások eredményei alapján tudjuk csak megítélni. A jövőbeli validációs célokra fejlesztett mérőeszközünk maga is validálásra szorul, akár egy megfigyeléses vizsgálat eredményeivel való összehasonlításban, akár tanári és szülői kérdőívváltozatok regisztrálásával és korreláltatásával. Egyelőre tehát nem állíthatunk biztosat a tanulók tényleges képességeiről, mindazonáltal valószínútlennek tűnik, hogy akár a saját kutatásunkban, akár a PISA-mérésben részt vevő tanulók ilyen nagy százaléka rendelkezik kiemelkedő kollaboratív képességekkel, a válaszadók közül sokan jó eséllyel felülértékelték saját magukat.

Kutatási kérdésként fogalmazhatjuk meg a jövőre nézve, hogy vajon a tanulók tisztában vannak a kollaborációs képességek 21. században képviselt értékével, és ennek kapcsán az elvártnak gondolt válaszokat adták, vagy ilyen mértékben irreális az önértékelésük a konstruktummal összefüggésben. Amennyiben az utóbbi magyarázat túnik helyesnek, mi lehet ennek az oka? Miért győzik meg magukat a tanulók arról, hogy jó csapatjá tékosok? Adataink egyértelmúen arra mutatnak, hogy a tanulók fontosnak tartják az együttmúködésre való képességet, amelyet mindenképpen pozitívumként könyvelhetünk el.

Említést kell tennünk végezetül az eredményeink általánosíthatóságának mértékét gyengítő tényezőkről. A kutatásban részt vevő diákok mindössze fele adott a 36 tételes kérdőív minden kérdésére választ, ez volt az a minta, amelynek adataira támaszkodva elemzéseinket elvégeztük. A többi tanuló - akár figyelmetlenség miatt, akár szándékosan - legalább egy álítást nem értékelt. A jelentős adatvesztés hátterében feltehetően az is közrejátszott, hogy a tanulók, mire eljutottak a szóban forgó kérdőívtételekhez, megoldottak egy vizuális memória és egy divergens gondolkodás tesztet, amelyek minden bizonnyal komoly kognitív kapacitást követeltek tólük. Ezen felül egy 45 tételes demográfiai kérdőívet is kitöltöttek. A teszt végére feltehetőleg sok diák elfáradt, mo tivációját vesztette. Ez azt jelenti, hogy a megerősítő faktoranalízis eredménye egy olyan minta adatain alapul, amelynek tanulói potenciálisan nagyobb figyelmi kapacitással rendelkeznek, motiváltabbak, szabálykövetőbbek az átlagnál. Annak ellenőrzésére, hogy a faktorstruktúra kevésbé szelektált minta eredményei mögött is kimutatható-e, érdemes lenne az adatfelvételt olyan feltételekkel megismételnünk, amelyek kapcsán kevésbé terheljük a tanulókat elózetes vizsgálatokkal, továbbá expliciten felhívjuk a figyelmüket arra, ha válaszadásuk hiányos.

\section{Köszönetnyilvánítás}

A kutatást az OTKA K115497 kutatási projekt támogatta. 


\section{Irodalom}

1. Binkley, M., Erstad, O., Herman, J., Raizen, S., Martin, R., Miller-Ricci, M. \& Rumble, M. (2012). Defining twenty-first century skills. In Griffin, P., McGaw, B. \& Care, E. (Eds.), Assessment \& teaching of 21st century skills (pp. 17-66). New York: Springer.

2. Brannick, M. T., Prince, A., Prince, C., \& Salas, E. (1995). The measurement of team process. Human Factors, 37(3), 641-651.

3. Cannon-Bowers, J. A. \& Salas, E. (1997). A framework for developing team performance measures in training (pp. 45-62). In M. T. Brannick, E. Salas, \& C. Prince (Eds.), Team performance assessment and measurement (pp. 331-355). Mahwah, NJ: Erlbaum.

4. Cannon-Bowers, J. A., Tannenbaum, S. I., Salas, E. \& Volpe, C. E. (1995). Defining competencies and establishing team training requirements. In R. Guzzo, \& E. Salas (Eds.), Team effectiveness and decision making in organizations (pp. 333-380). San Francisco: Jossey Bass.

5. Cumming, J., Woodcock, C., Cooley, S. J., Holland, M. J. \& Burns, V. E. (2015). Development and validation of the groupwork skills questionnaire (GSQ) for higher education. Assessment \& Evaluation in Higher Education, 40(7), 988-1001.

6. Csapó, B., Lórincz, A. \& Molnár, G. (2012). Innovative assessment technologies in educational games designed for young students. In D. Ifenthaler, D. Eseryel, \& X. Ge (Eds.), Assessment in game-based learning: foundations, innovations, and perspectives (pp. 235-254). New York: Springer.

7. Griffin, P., \& Care, E. (Eds.). (2015). Assessment \& teaching of 21st century skills. Methods and approach. Dordrecht: Springer.

8. Hao, J., Liu, L., von Davier, A. A. \& Kyllonen, P. C. (2017). Initial steps towards a standardized assessment for collaborative problem solving (CPS): Practical challenges and strategies. In A. von Davier, M. Zhu. \& P. Kyllonen (Eds.), Innovative Assessment of Collaboration (pp. 135-156). Springer International Publishing.

9. Hesse, F., Care, E., Buder, J., Sassenberg, K. \& Griffin, P. (2015). A framework for teachable collaborative problem solving skills. In P. Griffin, \& E. Care (Eds.), Assessment \& Teaching of 21st Century Skills. Methods and Approach (pp. 37-56). Dordrecht: Springer.

10. Józsa, K. (1999). Mi alakítja az énértékelésünket fizikából? Iskolakultúra, 9(10), 72-80.

11. Kanter, R. M. (1994). Collaborative advantage: The art of alliances. Harvard Business Review, 72(4), 96-108.

12. Kasik, L. (2013). Együttmúködés kérdőív. SZTE BTK Neveléstudományi Intézet.

13. Klein, C., DeRouin, R. E. \& Salas, E. (2006). Uncovering workplace interpersonal skills: A review, framework, and research agenda. In G. P. Hodgkinson, \& J. K. Ford (Eds.), International review of industrial and organizational psychology (pp. 80-126). New York: Wiley \& Sons Ltd.

14. Lewis, K. (2003). Measuring transactive memory systems in the field: scale development and validation. Journal of Applied Psychology, 88(4), 587-604.

15. Lim, B. C. \& Klein, K. J. (2006). Team mental models and team performance: A field study of the effects of team mental model similarity and accuracy. Journal of Organizational Behavior, 27(4), 403-418.

16. Liu, L., Hao, J., von Davier, A., Kyllonen, P. \& Zapata-Rivera, D. (2016). A tough nut to crack: Measuring collaborative problem solving. In Y. Rosen, S. Ferrara, \& M. Mosharraf (Eds.), Handbook of research on technology tools for real-life skill development (pp. 344-359). Hershey, PA: IGI Global.

17. Loughry, M. L., Ohland, M. W. \& DeWayne Moore, D. (2007). Development of a theory-based assessment of team member effectiveness. Educational and Psychological Measurement, 67(3), 505-524.

18. Molnár, Gy. (2015). A képességmérés dilemmái: a diagnosztikus mérések (eDia) szerepe és helye a magyar közoktatásban. Géniusz Múhely Kiadványok, 2, 16-29.

19. Molnár, Gy. \& Csapó, B. (2018a). Technology-based diagnostic assessments for identifying early learning difficulties in mathematics. In A. Fritz-Stratmann, P. Räsänen, \& V. Haase (Eds.), International handbook of mathematical learning difficulties. Springer. In press.

20. Molnár, Gy., Makay, G. \& Ancsin, G. (2018). Feladat- és tesztszerkesztés az eDia rendszerben. Szeged: SZTE Oktatáselméleti Kutatócsoport. 
21. Nagy, J. (2003). Az eredményesebb képességfejlesztés feltételeiről és lehetőségeiről. Iskolakultúra, 13(8), 40-52.

22. National Research Council (2011). Assessing 21st century skills. Washington, DC: National Academies Press.

23. Neubert, J., Mainert, J., Kretzschmar, A. \& Greiff, S. (2015). The assessment of 21st century skills in industrial and organizational psychology: Complex and collaborative problem solving. Industrial and Organizational Psychology: Perspectives on Science and Practice, 8(2), 238-268.

24. OECD (2013). PISA 2015 draft collaborative problem solving assessment framework. Retrieved from http://www.oecd.org/pisa/pisaproducts/Draft\%20PISA\%202015\%20Collaborative\%20Problem \%20Solving\%20Framework\%20.pdf

25. OECD (2017). PISA 2015 results (Volume V): Collaborative problem solving. Paris: OECD.

26. O'Neil Jr, H. F., Chuang, S. \& Chung, G. K. W. K. (2003). Issues in the computer- based assessment of collaborative problem solving. Assessment in Education, 10(3), 361-373.

27. Pásztor-Kovács, A. (2015). Kollaborativ problémamegoldó képesség: egy új, integratív elméleti keret. Iskolakultúra, 15(2), 3-16.

28. Pásztor-Kovács, A. (2018). A kollaborativ problémamegoldó képesség mérése. PhD értekezés. SZTE-BTK Neveléstudományi Doktori Iskola.

29. Pásztor-Kovács, A., Pásztor, A. \& Molnár, Gy. (2018). Kollaboratív problémamegoldó képességet vizsgáló dinamikus teszt fejlesztése. Magyar Pedagógia, 118(1), 73-102.

30. Salas, E., Cooke, N. J., \& Rosen M. A. (2008). On teams, teamwork, and team performance: discoveries and developments. Human Factors, 50, 540-548.

31. Smith-Jentsch, K. A., Cannon-Bowers, J. A., Tannenbaum, S. I. \& Salas, E. (2008). Guided team selfcorrection: Impacts on team mental models, processes, and effectiveness. Small Group Research, 39(3), 303-327.

\section{Development of a self-reported questionnaire to validate a theoretical model of Collaborative Problem Solving: exploring the collaborative component}

In this paper a self-reported questionnaire exploring the collaborative component of Collaborative Problem Solving (CPS) and the results of its testing are presented. The aim of the study was (1) to create such an instrument based on one of the theoretical models of CPS which gives feedback on individual level and describes general collaborative skills (does not base the judgement on a single situation); (2) to deepen our knowledge about the structure of CPS skills by validating a theoretical model of it. The questionnaire was built on the col laborative component of the model created by the Assessment \& Teaching of 21st Century Skills project experts. 36 items were developed to assess the three main skills and the nine subskills within. Students could rate on a five-point scale how much a given statement described them. The questionnaire was tested in the framework of a large-scale online data collection via the eDia online diagnostic platform by 8th grade students $(\mathrm{N}=871)$. Confirmatory factor analysis was applied to test whether the theoretical model appeared behind our dataset. After removing the items with low factor loadings the remained 17 items fitted to a three dimensional model $(x 2=386.06 \mathrm{df}=116 ; \mathrm{p}<0.01 ; \mathrm{CFI}=0.918 ; \mathrm{TLI}=0.904$; RMSEA $=0.052)$ so the three main collaborative skills (participation, perspective taking, social regulation) of the ATC21S model were clearly outlined. The reduced, 17 -item scale (Cronbach- $\alpha=0.91$ ) and its subscales (Cronbach- $\alpha=0.70-0.85)$ give an estimation of students' collaborative skills with an eligible level of reliability.

Keywords: collaborative skills, collaborative problem solving, cooperation, collaboration, Collaborative Skills Questionnaire 